\title{
Article
}

\section{Unmaking the Tricolore: Catherine Flon, Material Testimony and Occluded Narratives of Female-Led Resistance in Haiti and the Haitian Dyaspora}

\author{
Willson, Nicole Louise \\ Available at http://clok.uclan.ac.uk/30592/ \\ Willson, Nicole Louise ORCID: 0000-0001-5935-9075 (2020) Unmaking the \\ Tricolore: Catherine Flon, Material Testimony and Occluded Narratives of \\ Female-Led Resistance in Haiti and the Haitian Dyaspora. Slavery \& Abolition, \\ 41 (1). pp. 131-148. ISSN 0144-039X
}

It is advisable to refer to the publisher's version if you intend to cite from the work. http://dx.doi.org/10.1080/0144039X.2019.1685254

For more information about UCLan's research in this area go to http://www.uclan.ac.uk/researchgroups/ and search for <name of research Group>.

For information about Research generally at UCLan please go to http://www.uclan.ac.uk/research/

All outputs in CLoK are protected by Intellectual Property Rights law, including Copyright law. Copyright, IPR and Moral Rights for the works on this site are retained by the individual authors and/or other copyright owners. Terms and conditions for use of this material are defined in the policies page. 


\title{
Unmaking the Tricolore: Catherine Flon, Material Testimony and Occluded Narratives of Female-Led Resistance in Haiti and the Haitian Dyaspora
}

\begin{abstract}
The Haitian Revolution of 1791-1804 was the most radical antislavery and anticolonial struggle of the modern Atlantic World, and the only successful slave revolution. Yet the dominant, white-authored colonial archive, which privileges written texts over forms of nonliterary expression that flourished in the archive of slavery, conspicuously occludes the historical agents at its locus. While Haiti scholar Michel-Rolph Trouillot set a precedent for rehabilitating these histories, the voices of the women that were so central to this historical moment remain concealed, peripheral and ultimately ignored. Using a creative interdisciplinary methodology, this article interrogates how unarticulated narratives of Haiti's revolutionary women might be reassembled from disparate sources, looking closely at the mythologised figure of Catherine Flon, who purportedly sewed together the first Haitian flag at the Congress of Arcahaie on 18 May 1803. It also examines how artists and community groups in Haiti and across the Haitian dyaspora aim to preserve such figures for posterity.
\end{abstract}

\section{Author Biography}

Nicole Willson is a Black Atlantic scholar whose work engages with literary, visual and material culture from the Age of Slavery to the present. She was the Postdoctoral Research Assistant on the AHRC-funded 'Our Bondage and Our Freedom: Frederick Douglass and Family, 1818-2018' project at the University of Edinburgh, and is now a Leverhulme Trust Early Career Fellow at the Institute for Black Atlantic Research at the University of Central Lancashire. Her monograph entitled Caribbean Convulsions: Haiti, America and the Interdisciplinary Archive will be published in 2020 by Edinburgh University Press.

\section{Keywords}

Haiti, Haitian Revolution, Haitian art, Catherine Flon, material culture, dyaspora 


\section{Demystifying Haiti’s Revolution(s)}

Once lauded in the colonial imaginary as the 'pearl of the Antilles' for its flourishing plantation economy - an economy that, on the eve of revolution, generated around fifty percent of the world's coffee and sugar exports - the French colony of Saint-Domingue was eventually ravaged by the very system of colonial violence and brutality that had forged it into being. ${ }^{1}$ By the middle of the eighteenth century, the burgeoning colony's widening racial divisions were exacerbated by the expansion of white colonial settlement, increasingly stringent colonial legislation diminishing the legal status, public conduct and purchasing power of citizens of colour, and an increasingly ruthless and repressive plantation infrastructure undergirded by an unrestrained transatlantic slave trade. ${ }^{2}$ The response of the Black populace (both enslaved and free) was articulated in a twelve-year campaign of political and military resistance. What began as a series of discrete uprisings by enslaved people (that were initially suppressed) in the colony's northern provinces in 1791 grew into a colossal revolutionary conflict which led to the eventual overthrow of the colonial government and the formation in 1804 of the first Black republic. Renamed 'Haiti' in a gesture of commemoration to the Native Taino population that once inhabited the land that they called 'Ayiti' (meaning mountainous land), the citizens of the new nation state (that in fact became two nation states in the wake of the revolution) symbolically rejected the nomenclature of European colonisation. ${ }^{3}$

This synopsis of the Haitian revolutionary saga invariably simplifies a complex and multifaceted conflict that does not fit neatly within a linear historical paradigm. The military campaign that was spearheaded by enslaved rebels such as Georges Biassou, Jean-François Papillon and Jeannot, and eventually co-opted by Toussaint Louverture, was deeply sectarian in nature. Louverture, for example, is often heralded in historical accounts as the protagonist of Haitian independence and martyr of the anticolonial and antislavery struggle. Yet he fought variously for the Spanish and French colonial forces and presided over the reinstatement of a system of forced labour after the formal abolition of slavery. ${ }^{4}$ Furthermore, it was not until late in 1802, by which time Louverture had been apprehended by French colonial authorities and transported to the remote confines of Fort de Joux in the French Alps, that Jean-Jacques Dessalines and Henry Christophe defected from the French army and launched a targeted campaign of independence. Beyond the conflicting allegiances of the rebel leaders, geographical cleavages emerged between a northern territory dominated by a predominantly Black and formerly enslaved rebel army and a South contested by a light- 
skinned coloured elite. As such, the revolution cannot be readily characterised as a conflict between Blacks and whites, nor between coloniser and colonised. Nor should it be understood in purely military or political terms that privilege discourses of violent change or momentous events. Indeed, such terms obscure the varied and often neglected, though strategically fundamental, forms of insurgency articulated through subaltern countercultures, female ingenuity and creolisation that so often elude the colonialist archive. Confronting these complexities illuminates the manifold elisions, embellishments, misrepresentations and acts of violence to which Haiti's past (and indeed present) have been subjected, and demonstrates the failure of historical narratives, and the archive that underpins them, in fulfilling the objective of historical recuperation. While Haitian Studies scholars, indebted to the pioneering work of Michel-Rolph Trouillot, who highlighted the 'absences embodied in sources' held in archives that are 'neither neutral or natural' have sought to engage over the past three decades in an 'unearthing of silences', there is still much work to be done. ${ }^{5}$

This is most especially the case for the insurgent stories of women that remain occluded by the archive, and whose experience are most often inscribed in what transatlantic scholar Danielle Skeehan calls 'extra-discursive or material texts', which may have variously manifested as textiles, folklores, songs, dances or spiritual practices. ${ }^{6}$ Such expressive modes secrete the diverse and unexplored possibilities of women's insurgent histories. In order to expand the contours of the unarticulated insurgent experiences of women in the Haitian Revolution, it is incumbent on Black Atlantic and Haitian Studies scholars to adopt creative and interdisciplinary strategies that attempt to penetrate the cryptic traces that pervade colonial texts and seek out alternative narratives beyond the text to create a new archive of possibilities. ${ }^{7}$ This article embraces such strategies of creative interdisciplinarity through an in-depth focus on the material significance of textiles in articulating women's insurgent stories. In particular, it considers how such 'extra-discursive texts' might be employed to expand the radical possibilities of the much mythologised figure of Catherine Flon who, according to narrative accounts, created the first Haitian flag at the Congress of Arcahaïe in 1803. In following these extra-discursive material traces, it also examines the ways in which artists in Haiti and across the Haitian dyaspora have resurrected such strategies to redefine Catherine Flon's occluded history and recuperate her memory for Haitian women in the present.

\section{The Fabric of Power: Texts, Textiles and Female Insurgency}


Textiles were at the centre of the transatlantic nexus of trade, capital and movement in the age of slavery, and women of colour, both enslaved and free, were the principal vectors for their production and circulation. As Sophie White has highlighted, cloth was a valuable and highly prized commodity in the eighteenth-century Atlantic world, which had the 'potential [...] to assert or contest status, to construct community and economic agency, to facilitate or disrupt inter- and intra-ethnic power relations, and even to engineer social control within black spaces' ${ }^{8}$ Black women were inevitably exploited for their labour in the agricultural production of crops such as cotton and indigo and the domestic upkeep of plantation households through the manufacture and care of garments. In this way, however, textiles provide unique and vital testimonies of Black female ingenuity and creativity, informing a narrative of insurgency that is deeply intertwined with female domestic labour and production that written histories often occlude. ${ }^{9}$ By actively engaging with the possibilities that these extra-discursive texts elicit, it is not only possible, but vitally necessary, to expand the narrative parameters of Haiti's revolutionary history, which continues to privilege the legacies of its gwò negs (or big men), to encompass articulations of female radicality.

Examining the literary history of the Haitian Revolution in isolation from these extradiscursive sources can only ever offer access to an incomplete colonialist history replete with accounts of Black militarism that, as Raphael Hoermann suggests, privileges the symbolic value of masculinity and conspicuously occludes the ways in which women engaged in the revolutionary conflict. ${ }^{10}$ As Haitian Studies scholar Philippe Girard highlights, even those women acknowledged in the historical record are often only ever represented as 'anonymous entities'. ${ }^{11}$ Of course, as Marlene Daut has highlighted, colonial texts provide occasionally useful insights into the lives of women in the Haitian Revolution, despite their occlusions, omissions and distortions. In fact, these rhetorical strategies may represent an effort to constrain the 'obstinate, influential, radical, and even revolutionary' possibilities of such women. ${ }^{12}$ Colonial commentators such as the Baron de Wimpffen and Moreau de SaintMéry, for example, strove to denigrate women of colour for their perceived love of finery, but thereby inadvertently revealed secrets about their creativity and material literacy. ${ }^{13}$ Sara E. Johnson has also suggested that textual sources provide 'fragmentary traces' that, read alongside 'visual prompts, and sonic sources', provide a multidisciplinary vehicle for the speculative 'reassembly' of invisibilised figures. ${ }^{14}$ In essence, this is a blueprint for creative interdisciplinarity: by scrutinising the occlusions of the archive and seeking out material sources that bear the 'traces' of female agency, women's revolutionary narratives can be creatively reassembled. Although such strategies may not ultimately fulfil the aim of 
subverting the anonymity of Haitian women rebels, they provide a series of alternative narratives that are crucial to democratising and decolonising the archive that facilitates a reassessment of the existing record.

The aim of foregrounding the importance of material sources, and textiles in particular, in examining existing archival material, is to open up a range of previously unexplored discursive possibilities relating to female radicality. This approach can be usefully applied, for example to the notorious letter sent by Charles Emmanuel Leclerc to Napoleon during the French expedition to recapture Saint-Domingue, in which Leclerc advanced the proposition to 'destroy all the blacks of the mountains - men and women - and spare only the children under twelve years of age', further urging ' $[\mathrm{w}] \mathrm{e}$ must [...] not leave a single colored person in the colony who has worn an epaulette. ${ }^{15}$ Not only is this textual fragment revealing for its inherent anxiety around the insurgent memories of both men and women that were perceived as a collective threat to the preservation of the colonial order that Leclerc was commissioned to restore in Saint-Domingue, but also for its allusion to materialities that encapsulate complex and diverse revolutionary stories. The 'epaulettes' to which Leclerc alludes symbolically recall the ideals of republican virtù, compounding the revolutionaries' bold and insurgent claim to French citoyenneté. As C. L. R. James has noted, such trappings of the French colonial order were re-appropriated by the revolutionary armies in their fight against the expeditionary forces, forming part of the revolutionary 'assemblage' of resistant strategies and autonomous narratives. ${ }^{16}$ However, examining such allusions with creative interdisciplinary scrutiny sheds light on the labour, creativity and strategies of endurance that defined the revolutionary experiences of many women of colour in the Haitian revolutionary saga. Skilled in domestic crafts associated with the production and care of garments, women of colour incontestably contributed to this process of 'assemblage', helping to manufacture, repair and repurpose military uniforms. By so doing, they helped to create an iconography of the Haitian revolutionary experience that would become indelibly imprinted on the memories of French colonial expeditionary forces and consigned to posterity in written texts. Although the names and individual stories of Haitian revolutionary women in many cases remain invisibilised, such examples therefore demonstrate how other revolutionary narratives might be cryptically embedded within colonial texts. They also signal to the ways that creative interdisciplinary strategies for their interpretation might be effectively deployed to recuperate some of these stories.

Creative interdisciplinary strategies are especially integral to rehabilitating the unwritten and highly mythologised story of Catherine Flon, who is at the centre of a flag- 
creation narrative that has become integral to the collective memory of Haitian independence. According to popular accounts, Catherine Flon was the goddaughter Jean-Jacques Dessalines. A nurse and a seamstress, Flon was purportedly commissioned by Dessalines at the Congress of Arcahaïe (which saw the leading revolutionary generals converge under a single, unified aim of independence on 18 May 1803) to stitch back together the red and blue panels of the French tricolore after he had torn out its white central panel, thereby creating the Haitian bicolore. Although this narrative is enshrined within the diasporic and transgenerational framework of oral history, and has no doubt been subject to embellishment and fabrication, it renders visible and tangible the revolutionary stories of women of colour. In particular, it acknowledges their material contributions to the military campaigns and invites them into the public revolutionary arenas from which they were typically precluded in the written historical record.

Catherine Flon, like so many other women that contributed to the revolutionary saga, occupies the silent, interstitial and secretive spaces of the textual archive. Any surviving trace of her real lived identity can only be recovered from spurious sources. And her story has been co-opted by colonialists and nationalists alike for unscrupulous purposes. Unlike revolutionary icons such as Louverture, Dessalines and Christophe, her story is fragmented and largely 'unverified'. Indeed, Philippe Girard discredits her very existence along with the ceremonious unmaking of the tricolore which supposedly took place at the Arcahaie Congress which he says has been subject to 'ex post facto mythologizing on a similar scale to the extensive folklore surrounding the Bois Caïman ceremony' (the Vodou ceremony which purportedly preceded the slave revolt on the plantation of Lenormand de Mézy that marked the beginning of the Haitian Revolution). He further notes that '[a]rchival sources support few of the details found in the popular version of the flag's creation'. ${ }^{17}$ As a historian working predominantly within the colonialist archive, Girard places disproportionate weight on the value of written texts and conventional forms of authorship that were often inaccessible to women of colour in slave societies. He also significantly overlooks the manifold ways in which such women created their own historic legacies (not least the figure of Catherine Flon, who is subject to only a cursory analysis in his examination of the creation of the Haitian flag). However, such observations highlight the need to exercise caution in accepting as fact mythic constructions of women revolutionaries and interrogate whose interests such mythologies might serve.

It cannot be assumed, for example, that because such narratives are so tightly interwoven with oral history that they necessarily came 'from below', to borrow the 
terminology used by Carolyn Fick to articulate the grassroots resistance movement of the enslaved populace of Saint-Domingue within the Haitian revolutionary saga. The Haitian journalist Roxanne Fequière, for example, describes how Haitian Flag Day (which is commemorated each year on May 18 on the alleged date of the Arcahaie Congress) was 'once marked by compulsory demonstrations of national pride under the dictator François Duvalier' ${ }^{18}$ Such depictions problematise the narratives that enshrine Catherine Flon within the collective memory and make it difficult to extricate those narratives from the infrastructures of political opportunism. This is compounded by the fact that the figure of Catherine Flon has been used on the dix gourdes banknote, which was first issued in 1988 in a year marked by political instability that saw several candidates accede to the presidency. In a society in which women are counted among the most financially precarious, it is also difficult to perceive such gestures as anything other than lip-service to the effort of historical recuperation and female uplift. Pageants such as the 'Miss Catherine Flon' contests held annually throughout Haiti around the date of Haitian Flag Day further undermine the radical possibilities of women's revolutionary histories by confining them to the realm of the specular and the corporeal.

Nevertheless, while Fequière's article demonstrates how these mythic stories might be used as ideological weapons to effect hegemonic control by elites, it also illustrates the active roles that women have played in nurturing and communicating stories of family, community and subalternity in order to preserve the unwritten memories of their ancestors. An image of the author's mother, aunt and cousin preparing a Flag Day feast captured by photographer Winnie Au (Figure 1) powerfully highlights the transgenerational vitality of such stories and the centrality of women in shaping them. It also underscores the social importance of skills connected with caregiving, domestic labour and creativity that are so central to the story of Catherine Flon. The symbiosis between revolutionary creativity and female domestic labour that Flon's memory embodies is also compounded by Au's photographic composition of the Fequiére family feast, which features a plate of griot (or spiced pork) with rice and beans centred on top of the Haitian bicolore (Figure 2).

Figure 1: Photograph of Margaret Moise, MarieYolens Fequiere and Bryanna Fabre. (C) Winnie Au 2019. Reproduced with the permission of Winnie Au.

Figure 2: Photograph of griot, rice and beans served on a Haitian Flag. () Winnie Au 2019. Reproduced with the permission of Winnie Au. 
In her seminal Haiti, History and the Gods, Colin Dayan asks the important question '[w] hat happened to actual black women during Haiti's repeated revolutions, as they were mythologized by men, metaphorized out of life into legend? It is unsettling to recognize that the hyperbolization necessary for myths to be mutually reinforcing not only erases these women but forestalls our turning to these real lives'. ${ }^{19}$ Ultimately, public histories that valorise women revolutionary figures such as Catherine Flon demand an analytical approach that strike a critical and imaginative balance: one that recognises the centrality of what Jana Evans Braziel has termed 'bios' and 'mythos' and the roles that women have played in shaping these stories. ${ }^{20}$ While no comprehensive study has yet to truly delve into the 'real lives' of Haitian revolutionary women, such challenges as Dayan's demand the need for creative interdisciplinary scholarship that situates women as protagonists within their own histories. Regardless of whether or not the story of Catherine Flon can be accepted as fact, her story is part of the rich tapestry of Haitian revolutionary identities and, as symbol, and as remnant, she represents the multitude of nameless women of colour who used textiles as an expressive medium to articulate their revolutionary experiences. And certainly, even if there was no real personality named Catherine Flon, it might safely be assumed that there was at least one woman, if not a series of women, who were involved in the flag's creation at Arcahaïe or elsewhere.

Documentary evidence points to the fact that enslaved seamstresses proliferated in prerevolutionary Saint-Domingue. Notices posted in the Saint-Domingan newspaper Affiches américaines between 1766 and 1791, for example, offer dozens of examples of 'couturières' (seamstresses) listed among those enslaved people 'A Vendre' (for sale). These notices also reveal that such women had a myriad of other domestic skills connected with the production, care and distribution of textiles. Some of those listed as 'couturières' are also listed as 'blanchisseuses' or 'lingères' (laundresses), 'marchandes' (merchants or traders) and 'ménagères (housekeepers). Other examples provide evidence of seamstresses working as cooks and nurses. ${ }^{21}$ Such a catalogue of skills was undoubtedly vital to a plantation economy in which textiles circulated as currency for Black bodies. Yet it was also central to the eventual unmaking of that economy. Women with such a wide array of domestic skills played integral roles in revolutionary battle camps, for example, especially as sutlers, nurses and cooks. As Girard highlights, maids and merchants were ideally positioned to engage in acts of espionage and women outside of the encampments 'took over tasks that were seen as essential to the ultimate victory, such as growing provisions'.22 These women performed the 
necessary domestic and emotional work that fortified and emboldened a revolutionary army that suppressed the advances of French colonial expeditionary forces.

Perhaps more tellingly, notices from the Affiches américaines found exclusively on the 'Marronage dans le Monde Atlantique' database reveal that such women were by nature rebellious, and rejected the colonial system through their own acts of insurgency and fugitivity. In a notice posted on 14 February 1784, it is revealed that a woman by the name of Madeleine and labelled as a 'Créole', aged between the age of 22 and 24 and recognised as an 'excellente couturière $\&$ brodeuse, parlant bien français \& ayant été élevée à Paris, maronne depuis le mois d'Août dernier' (an excellent seamstress and embroiderer, speaking good French and having been raised in Paris, ran away last August). ${ }^{23}$ Such notices offer a window into the radical possibilities of the enslaved women so often ignored by the written history of the Haitian Revolution, and the radical opportunities proffered by the needle. They also tell us about the intellectual capabilities of such women and the levels of training that they may have had access to, especially as they moved throughout the Atlantic world as enslaved women such as Madeleine are recorded as having done. In a notice published in August of the same year, another enslaved 'Créole' named Marie described as a 'couturiére' who is 'généralement bien vêtue, \& a la vanité de se dire libre quand elle n'est pas connue' (generally well dressed and has the vanity of passing herself off as free when it is not known) is listed as having absconded the previous month. It is also noted that, in addition to passing herself off as free, and dressing herself in such a way that might make her appear so, 'on soupçonne avoir suivi un Mulâtre fugitif, nommé Colin' (she is suspected to have followed a fugitive mulatto named Colin). ${ }^{24}$ Such notices reveal that not only were women able to use textiles to radically subvert their identities, but they also supported, followed and conspired with others in performing these acts of subversion. With their diverse range of domestic skills and a predisposition toward acts of physical and creative insurgency, these women undoubtedly proved themselves to be of vital importance to the revolutionary cause. These women are celebrated in the figure of Catherine Flon.

Material texts, where they can be recovered, undoubtedly provide more complex and personalised insights into women's revolutionary lives. While a handful of these sources can be found dispersed across archives in the North Atlantic and circum-Caribbean, they have in most cases been incorrectly catalogued, damaged and disconnected from any source of information about their provenance. The Costumes and Textiles Collection at the Louisiana State Museum, for example, holds two head wraps of purported Saint-Domingan origin, but it is only possible to speculate about the personal histories of their owners. ${ }^{25}$ As literacy rates 
among enslaved and free women of colour in the age of slavery were disproportionately low, self-authored accounts offering any insight into how such sources might be interpreted are rare; their stories remain inscribed in the material objects that they possessed, created and passed on. Existing fragments nevertheless provide complex insights.

The archive of Marie Bunel, a Saint-Domingan woman of colour who was married to the white diplomat who served as envoy to Toussaint Louverture and later moved to Philadelphia, contains a number of letters from Marie-Louise Christophe, the wife of the revolutionary General that would, in post-independence Haiti, become crowned King Henry I. In a letter sent to Madame Bunel on 3 June 1809, Marie-Louise enumerates a long list of goods that she requires Bunel to send to her in Haiti, including a number of ready-made garments and raw materials for the manufacture of clothing, such as 'chemises des couleurs cramoisi, Rozé, Bleue ciel, viol[i]ne, aurore, Lilas, Bleue de roy, en vert tendre' (shirts in the colours of crimson, red, sky blue, violet, dawn, lilac, royal blue and soft green), measures of 'galon de fêt, pour garniture' (ceremonial braids for embellishment), 'cordonnet[s]' (cording) and 'franger' (fringe), along with 'rubans' (ribbons) and 'fil de coton pour [Broder] au crochet' (cotton thread for crochet embroidery). ${ }^{26}$ These descriptions of the materials handled by the prospective queen are revealing for their insights into the kinds of relationships that even elite women of colour had with textiles.

While the stories of elite women of colour such as Marie-Louise Christophe who were born free and propertied do not necessarily correlate with the experiences of the the enslaved laundresses, dressmakers and merchants who likely deployed their skills repairing garments and salving wounds on the revolutionary battlefield like the mythic figure of Catherine Flon, they demonstrate how women contributed to and helped to reinforce emerging discourses of sovereignty and pride in the nascent Kingdom of Haiti. As a consort held up to international scrutiny, Marie-Louise was acutely aware of the ways in which her self-image could be disseminated and distorted, and strove to regulate her outward-facing identity. Skills bound up with the production and care of garments were not only integral to the domestic labour performed in enslaved households and on the battlefield, but were, and continue to serve as, essential revolutionary tools for Haitian women; these skills were crucial to the stories that they chose to author before, during and after the revolution.

Although these assessments are largely conjectural, they point to a wider archive of revolutionary performativity beyond the delimiting confines of the colonialist textual archive. By probing the interpretative depths and exploring the myriad meanings of extra-discursive texts, the revolutionary lives of Haitian women rebels can be imaginatively resurrected from 
archival silence and archival violence. Such 'imaginative' afterlives reveal how women of colour were able to carve out personal revolutionary identities in spite of barriers they encountered to forms of self-expression in the slaveholding Americas. Certainly, there is much work to be done here, and, as Marlene Daut argues, it is necessary 'to try to uncover' the " "real lives" of black women during the Revolution [...] even if doing so means to approach the topic in unconventional ways' ${ }^{27}$ By adopting unconventional strategiesstrategies informed by creative interdisciplinarity, it is newly possible to expand the radical parameters of Haiti's revolutionary history and the women that it continues to occlude, distort, omit and suppress. Haitian artists across the diaspora, or 'dyaspora' as it is termed in Kreyòl, have used such strategies to explore and articulate the radical possibilities of Catherine Flon's occluded history and recuperate her memory. In so doing, they have created new anticolonial and revolutionary narratives that reaffirm the fundamental revolutionary value of female domestic labour and emotional work and expound a narrative of womanist resistance that has currency in Haiti and across the Black Atlantic.

\section{'Poto Mitan': Women's Histories, Narrative Recuperation and Art in Haiti and the Haitian Dyaspora}

In her introduction to the exhibition catalogue for Kafou: Haiti, Art and Vodou, an exhibition that she co-curated with Alex Farquharson in 2012, the artist Leah Gordon observed that 'Haitian art and culture is a potent vessel for continually narrating, transmitting and reinterpreting the history of Haiti. As such, art is primarily a tool to keep history alive'. ${ }^{28}$ Undergirded by a rich revolutionary and diasporic history, Haitian art is a repository of public memory, and represents both a witness to the radical revolutionary moment and a strategy for effecting insurgency in itself. The poet, novelist and intellectual Jacques Roumain, for example, oversaw the establishment of a Bureau d'Ethnologie in Haiti-the first institution established to celebrate the Haitian cultural experience. Given pervasive impediments to literacy in Haiti — especially among the labouring poor — visual arts have proven to be more accessible. As such, they celebrate a multitude of subaltern revolutionary voices and experiences. Revolutionary symbols, themes and tropes are repeatedly invoked to transmit stories of political corruption, capitalist exploitation and western imperialism, but also to celebrate expressions of community, divinity and sovereignty that inform a narrative of cultural pride. Catherine Flon is a personality that has been reimagined in popular, folk and street art alike, and has been redeployed at crucial moments in Haiti's history to tell a 
different cultural story: a story that is nevertheless always expressive of the ongoing Haitian revolutionary experience.

One of the most canonical works of Haitian art featuring the figure of Catherine Flon is the painting of 'Dessalines Ripping the White from the Flag' by surrealist artist Madsen Mompremier (Figure 3). This painting presents an image of Catherine Flon seated beneath a tree with sprawling roots and branches and breasts growing out of its trunk, reinforcing the symbolic preeminence of maternity and nurture. It also recalls Louverture's analogy of the 'tree of liberty' with roots deep and numerous. ${ }^{29}$ As Catherine Flon sews the bicolore together, assisted in her labour by the phantasmagorical figure of a three-headed woman, Dessalines is depicted using his sword to strip the white panel from the French tricolore, which is held at the opposite corner by a seraph. He is encircled by an audience of rebel soldiers in full military regalia, complete with epaulettes and bicorn hats, along with a host of angels, fish and other mystical and metaphysical figures flourishing horns and bicolores. This is a process of simultaneous making and unmaking: of the deconstruction of the colonial order and the creation of a sovereign, anticolonial Haitian state. That there is a 'production line' with multiple flags being unmade and remade at the same moment and a 'blueprint' for the bicolore at the base of the tree, suggests that the work of revolution is continuous, ongoing and circular. The image celebrates Haitian femininity and female domestic labour; Catherine Flon is depicted wearing a large yellow head wrap - a garment that, as contemporary commentators such as Moreau de Saint-Méry observed, served both a utilitarian and decorative function in colonial Saint-Domingue and ultimately became a tool for subverting colonial assaults on forms of female self-expression. ${ }^{30}$ While much of Mompremier's oeuvre celebrates a sensual femininity as embodied by the Vodou lwa Lasiren (the mermaid), Ezili Freda (the goddess of love and beauty) and Ezili Dantò (the fierce and vengeful protector of women), his representation of Catherine Flon looks beyond the sensual and the corporeal to illuminate the creativity and ingenuity of the women of colour that created their own material testimonies of the revolutionary experience and the subversive and transformative power of the textiles that they used to create them.

\section{Figure 3: Madsen Mompremier, 'Dessalines Ripping the White from the Flag' (1995), oil on canvas, $77.2 \times 91.4 \mathrm{~cm}$. Courtesy of the Fowler Museum at UCLA.}

This celebration of women's insurgent creativity and ingenuity is extended in the work of Haitian artist Patricia Brintle, a member of the Haitian dyaspora who emigrated to the 
United States in 1964 but whose work remains entrenched in Haitian history and culture. Nowhere is this more apparent than in her historical series, which embraces the forgotten and occluded histories of Hispaniola's Native Taino population that was ravaged by European colonisation and rehabilitates the narratives of Haitian women revolutionaries including the soldier Jean-Marie Lamartinière, the sutler Dédé (Défilée 'La Folle') Bazile and Catherine Flon.

Figure 4: Patricia Brintle, 'Catherine Flon' (2011), oil on canvas, 122 x $91.4 \mathrm{~cm}$. Reproduced with the permission of Patricia Brintle.

In her painting of Catherine Flon (Figure 4), the subject is depicted in a yellow dress, echoing the colour palette of Mompremier which was selected, as Brintle observes, to connote that 'it was made of gold' in order to reinforce 'how precious she is' ${ }^{31}$ In this way, Brintle affirms the primacy of Catherine Flon, configuring her as a leading agent within the narrative of nation-formation. This is compounded by the fact that she is removed from the revolutionary context: she does not feature as a set-piece within the narrative of Dessalines and the Arcahaïe Congress as in Mompremier's painting. Instead, she is celebrated through the medium of historical portraiture as a leading revolutionary icon in her own right. Pictured seated while sewing against a backdrop of lush verdure with the rolling mountains of Haiti that are inscribed in its Taino name of Ayiti featuring prominently within this landscape, Catherine Flon is shown to be a metonym of Haiti, and her body and the flag are represented as having an organic connection with the land and the Haitian people's sovereign claim to it. The image encapsulates Brintle's guiding principles respecting Haitian womanhood and articulates a narrative of feminist and womanist resistance that she describes thus:

I love my country dearly and being one myself, I have an affinity for the Haitian woman. She is strong, nurturing, forgiving, resilient, very aware of her femininity, and always show[s] a beautiful smile. I admire women who are able to overcome the stereotypes and inequities that exist in Haiti and who have made an impact on the history of our country. Women in Haiti are called the 'Poto mitan' (central post) of the family and they certainly live up to that name.

I look up to the Heroines of the Revolution because they set an example for us today. The time and events may be different but it it the same courage and fortitude that is required to make a difference that will affect the future generation.. ${ }^{32}$ 
Like Brintle, the Haitian graffiti-artist Jerry Rosembert removes Catherine Flon from the revolutionary context, but instead re-situates her in the present. In a mural that he produced in the wake of the 2010 Haitian earthquake (Figure 5), Catherine Flon is depicted sewing the Haitian flag back together once again amid the rubble and devastation. This image celebrates the revolutionary resilience of Haitian culture and its capacity to rebuild and remake itself anew, and the integral emotional work of women in fulfilling this goal. The motto reads 'Haiti pap peri' (Haiti will never die). This is the ultimate story of reassembly and reaffirms that, whether or not Catherine Flon can be retrieved from the archive of the 'real', her memory is integral to the insurgent Haitian consciousness: to stories of creativity, labour, resilience and survival that repeat throughout Haiti's history.

Visual art is just one strand in a host of artistic and expressive modes that have been used in African diasporic cultures in the Americas to reproduce and archive stories of trauma, survival and resistance, and this multimodality in turn represents an articulation of the creole experiences of relation and routedness that postcolonial scholars such as Édouard Glissant and Paul Gilroy define as central to the New World experience. ${ }^{33}$ In Haiti in particular, artistic and expressive culture is a vehicle for creolistic countercultural practices, notably exemplified by Vodou, saturating the Haitian cultural imaginary and acting as a binding agent in all elements of daily life - from birth, death and marriage through to labour, festivity, nurture, healing and community-building. ${ }^{34}$ In this way, art is not simply a medium of articulation and representation, but is a necessary component within the larger machinery. Art is deeply ingrained, for example, in spiritual praxis; the drawing of veve, singing, dancing, oral storytelling and various other performative modes form the cornerstone of Vodou ceremonies. ${ }^{35}$ Vodou is, in this sense, a site of memory for the Haitian and Haitian diasporic experience, and art is the embodiment of what Dayan has called 'Vodou history' which, as Braziel notes, is disseminated through the various diasporic modes of 'chan (song), pwovèb (proverbs), and istwa (stories)' ${ }^{36}$

\section{Figure 5: Graffiti art attributed to Jerry Rosembert. Photograph reproduced with the permission of Paul Clammer.}

Haitian visual art draws on and interacts with various expressive modes in a way that is radically creative and interdisciplinary, and expands the parameters of the Haitian revolutionary narrative in a way that literary historical and archival scholarship cannot. As Brintle observes, 
[a]rtists are visual reporters. They tell the story on the canvas much like the troubadours did with song. Artists make an account through art of the current (or past) news that touch[es] them and they let their brush be guided by their emotions. As such, artist[s] in Haiti and in the diaspora tell the story for the future generations. ${ }^{37}$ This view underpins the artistic response to the archive and to the process of history-making that Haitian scholar Michel-Rolph Trouillot identified as the source of silence and mythproduction in the creation of Haitian revolutionary narratives. ${ }^{38}$ Art is perceived in Haitian culture as a vital and legitimate form of recording and archiving the Haitian experience, and thereby presents a challenge to the dominant white-authored, colonialist narratives that continue to suffuse the western metanarrative: a metanarrative characterised by ignorance, erasure and misrepresentation. ${ }^{39}$ It is, in its very nature, a rebellious, decolonial and democratising response. Although, as Trouillot argued, 'any historical narrative is a particular bundle of silences' that necessitate variable processes of deconstruction, ${ }^{40}$ art facilitates a multitude of performative responses, transgressing disciplinary boundaries and linear conceptions of time and place. As Haitian writer Edwidge Danticat exemplifies, '[t]he mix of seemingly incongruent elements in art [...] can also be called maronaj. It too can also be called doubling, shape-shifting, as part of a long tradition of resistance and selfpreservation. ${ }^{41}$ As a rebellious, polyphonous mode, it represents the ideal vehicle for a creative interdisciplinarity in practice that rehabilitates women within the framework of Haitian revolutionary history.

Nevertheless, while performative and expressive culture in Haiti offers an unprecedented platform for subaltern voices, and allows for the dissemination of revolutionary stories that the archive precludes, the artistic 'canon' remains heavily dominated by men. Few works by women artists have featured in the major international exhibitions on Haitian art over the past decade, and even the biennial Haitian art festival, Ghetto Biennale, established in 2009 as a protest against western states that denied entry visas to the artists whose artworks circulated in their exhibition spaces, has featured few Haitian women participants. ${ }^{42}$ Moreover, much of the work addressing women's experiences has centred on the divine worlds of the Vodou lwa rather than the lived experiences and mundane struggles of Haitian women. This is partly a reflection on the structural imbalances that prevail in Haitian society: as Leah Gordon observed in an interview with the author in 2012, Haitian women remain largely confined, especially in the households of the working poor, to the domestic sphere, and conventional gender roles remain so ingrained that 'no one bothers with feminism for poor women in Port-au-Prince' ${ }^{43}$ 
What this also reveals, however, is that there are realms of creativity that remain exclusive to women, such as domestic labour, with which scholarship is yet to fully engage. As in the revolutionary moment, Haitian women are excluded from the act of history-making because they operate outside of the conventional and dominant spheres of artistic production. While art, as a vehicle for creative interdisciplinarity, offers a model for combatting the silences of the archive, platforms for its dissemination such as museums and galleries must also strive to think more creatively about what represents art, and how the women that partake in various forms of performative and artistic creation can be repositioned within discourses of art-making. By situating women's experiences at the centre of the discussion, we can obtain new insights into the ways that women have creatively interpreted, archived and ultimately 'reassembled' their own histories.

\footnotetext{
${ }^{1}$ David Patrick Geggus, Haitian Revolutionary Studies (Bloomington: Indiana University Press, 2002), $5 ; 171$.

${ }^{2}$ For more on the social, political and economic context of the revolution see Laurent Dubois, Avengers of the New World: The Story of the Haitian Revolution (Cambridge and London: The Belknap Press of Harvard University Press, 2004); Carolyn Fick, The Making of Haiti: The Saint Domingue Revolution from Below (Knoxville: The University of Tennessee Press, 1990); John D. Garrigus, Before Haiti: Race and Citizenship in French Saint-Domingue (New York: Palgrave Macmillan, 2006); Geggus, Haitian Revolutionary Studies; James, C. L. R., The Black Jacobins: Toussaint L'Ouverture and the San Domingo Revolution (London: Penguin Books, 1938; repr. 2001).

${ }^{3}$ See Colin (Joan) Dayan, Haiti, History, and the Gods (Berkeley and Los Angeles: University of California Press, 1995), 3 and Dubois, Avengers, 13.

${ }^{4}$ Dubois, Avengers, 220.

${ }^{5}$ Michel-Rolph Trouillot, Silencing the Past: Power and the Production of History (Boston: Beacon Press, 1995), 48; 58.

${ }^{6}$ Danielle C. Skeehan, 'Caribbean Women, Creole Fashioning, and the Fabric of Black Atlantic Writing', The Eighteenth Century 56, no. 1 (2015): 106.

7 This is the guiding methodological premise of the author's doctoral dissertation. See Nicole Willson, 'Cryptic Secrets: Phantoms of the Haitian Revolution in the American Imaginary' (PhD diss., University of East Anglia, 2016), 31.

${ }^{8}$ Sophie White, 'Slaves and Poor Whites' Informal Economies in an Atlantic Context', in Louisiana:

Crossroads of the Atlantic World, ed. by Cécile Vidal (Philadelphia, University of Pennsylvania Press, 2014), 89-102 (92).

${ }^{9}$ Marlene Daut highlights that the scholarship of Barbara Bush, Bernard Moitt, Karol K. Weaver and Stephen Girard explore alternative forms of insurgency beyond the realms of armed combat in the Haitian Revolution. See Marlene L. Daut, Tropics of Haiti: Race and the Literary History of the Haitian Revolution in the Atlantic World, 1789-1865 (Liverpool: Liverpool University Press, 2015), 207.

${ }^{10}$ Raphael Hoermann, 'Gendered Representations of Haitian Revolutionary Heroism in Black Atlantic Culture' (paper presented at Konesans: New Perspectives on Haitian Studies in Europe, Newcastle University, 4-5 April 2019).

${ }^{11}$ Philippe Girard, 'Rebelles with a cause: Women in the Haitian War of Independence: 1802-04', Gender \& History 21, no. 1 (2009), 60-85 (71).

12 Daut, 204.

${ }^{13}$ Both Moreau and De Wimpffen wrote at length about the innovative ways that women of colour in SaintDomingue fashioned head wraps and the materials that they employed to create them. See Médéric Louis Élie Moreau de Saint-Méry, Description Topographique, Physique et Politique de la Partie Francaise de l'Isle Saint-Domingue, 2 vols, vol. 1 (Philadelphia: [n. pub.], 1798), 59; Francis Alexander Stanislaus, Baron de Wimpffen, A Voyage to Saint Domingo, in the Years 1788, 1789, and 1790, trans. by J. Wright (London: [n. pub.], 1817), 114.

${ }^{14}$ Sara E. Johnson, The Fear of French Negroes: Transcolonial Collaboration in the Revolutionary Americas (Berkeley and Los Angeles: University of California Press, 2012), xx; 52; 124.
} 
${ }^{15}$ Charles Emmanuel Leclerc to Napoleon Bonaparte, 7 October 1802, qtd. in Dubois, Avengers, 291-292.

${ }^{16}$ C. L. R. James, The Black Jacobins: Toussaint L'Ouverture and the San Domingo Revolution, second revised edition (New York: Vintage Books, 1963), 94.

${ }^{17}$ Philippe Girard, 'Birth of a Nation: The Creation of the Haitian Flag and Haiti's French Revolutionary

Heritage', Journal of Haitian Studies 15, nos. 1-2 (2009), 135-150 (135).

18 Roxanne Fequière, 'A Day to Celebrate Haiti's Flag, and Its Foods', New York Times, 14 May 2018,

https://www.nytimes.com/2018/05/14/dining/haiti-flag-day-cooking.html.

${ }^{19}$ Dayan, p. 48.

${ }^{20}$ Jana Evans Braziel, 'Remembering Défilée: Dédée Bazile as Revolutionary Lieu de Mémoire', Small Axe 9, no. 2 (2005), 57-85 (65).

${ }^{21}$ The Digital Library of the Caribbean in association with the University of Florida provides a searchable database of 52 volumes of the Affiches américaines between these dates. See 'Les Affiches américaines', University of Florida Digital Collection (n.d.), http://ufdc.ufl.edu/AA00000449/00027/allvolumes.

${ }^{22}$ Girard, 'Rebelles with a cause', 68-69.

${ }^{23}$ Affiches américaines, 14 February 1784, Le Marronage dans le Monde Atlantique, n.d., http://www.marronnage.info/fr/document.php?id=6710.

${ }^{24}$ Affiches américaines, 2 August 1784, Le Marronage dans le Monde Atlantique, n.d., http://www.marronnage.info/fr/document.php?id=8282.

${ }^{25}$ Willson, 121-122.

${ }^{26}$ Letter to Mme. Joseph Bunel from Marie Louise, Queen Consort of Henri Christophe, 3 June 1809, Haitian Collection, 1714-1916, Box 71, Boston Public Library.

${ }^{27}$ Daut, 219.

${ }^{28}$ Leah Gordon, 'Krèyon Pep La Pa Gen Gom (The People's Pencil Has No Eraser)', in Kafou: Haiti, Art and Vodou (Nottingham: Nottingham Contemporary (2012), 20-25 (21).

${ }^{29}$ Upon his arrest and transportation to France, Louverture is reported as having declared 'In overthrowing me you have cut down in Saint-Domingue only the trunk of the tree of liberty of the blacks: it will grow back from the roots, because they are deep and numerous.' Qtd. in Dubois, Avengers, 278.

${ }^{30}$ Moreau de Saint-Méry, 59.

${ }^{31}$ Patricia Brintle, email message to author, 29 March 2019.

32 Ibid.

${ }^{33}$ See Édouard Glissant, Poetics of Relation, trans. Betsy Wing (Ann Arbor: The University of Michigan Press, 1997), 33-34 and Gilroy, Paul, The Black Atlantic: Modernity and Double Consciousness (London and New York: Verso, 1993), 19.

${ }^{34}$ This is especially true of the konbit, a community-based labour collective fortified by communal festivity. See Jennie M. Smith, When the Hands are Many: Community Organization and Social Change in Rural Haiti (Ithaca and London: Cornell University Press, 2001), 86.

${ }^{35}$ Dayan, 79-142.

${ }^{36}$ Braziel, 69.

${ }^{37}$ Brintle.

38 Trouillot, 26.

${ }^{39}$ The popular western media narrative of Haiti is built on, and continues to circulate, a number of tropes relating to disaster, criminality and barbarism that it perceives as expressive of the Haitian experience and depicts Haitian people as abject victims of their own depredation. This popular set of assumptions was crystallised in comments made by President Donald Trump at a meeting held in the Oval Office with members of Congress in January 2018 in which he referred to Haiti along with a host of African nations as 'shithole countries'. See Julie Hirschfeld Davis, Sheryl Gay Stolberg and Thomas Kaplan, 'Trump Alarms Lawmakers With Disparaging Words for Haiti and Africa', The New York Times, 11 January 2018, https://www.nytimes.com/2018/01/11/us/politics/trump-shithole-countries.html.

40 Trouillot, 27.

${ }^{41}$ Edwidge Danticat, 'Preface', in In Extremis: Death and Life in $21^{\text {st }}$-Century Haitian Art (Los Angeles: Fowler Museum, 2012), 17-19 (18).

${ }^{42}$ Leah Gordon, 'Haitian Art: Multiple Ideologies Between the Altar, the Museum and the Market Place' (paper presented at Konesans: New Perspectives on Haitian Studies in Europe, Newcastle University, 4-5 April 2019). ${ }^{43}$ Leah Gordon, interview with author, 27 November 2012. 